\title{
Electrochemical Corrosion Behaviors of TiC Particles Reinforced Fe-based Composite Plasma Cladding Layers
}

\author{
Mingqi Tang ${ }^{1, *}$, Wen Wang ${ }^{2}$, Gang Li $^{1}$, Zaiqiang Feng ${ }^{1}$, Zhenwei Yan ${ }^{3}$, Na Zhang ${ }^{1}$, \\ Ruizhu Zhang ${ }^{l}$ \\ ${ }^{1}$ School of Materials Science and Engineering, North China University of Water Resources and \\ Electric Power, Zhengzhou 450045, China \\ ${ }^{2}$ School of Civil Engineering and Communication, North China University of Water Resources and \\ Electric Power, Zhengzhou 450045, China \\ ${ }^{3}$ School of Mechanical, North China University of Water Resources and Electric Power, Zhengzhou \\ 450045, China \\ *E-mail: tangmq400@163.com
}

doi: $10.20964 / 2019.02 .74$

Received: 3 November 2018 / Accepted: 11 December 2018 / Published: 5 January 2019

In-situ and ex-situ titanium carbide (TiC) reinforced Fe-based cladding layers were fabricated via the plasma cladding method using nitrogen as the protective and reactant gas. In-situ TiC particles in the cladding layer were prepared using $\mathrm{Ti}$ and boron carbide $\left(\mathrm{B}_{4} \mathrm{C}\right)$ powders as primary raw materials. The compositions, microstructures, and corrosion resistance of the cladding layers were compared. Results showed that in-situ TiC reinforced cladding layers consisted of $\alpha-\mathrm{Fe}, \mathrm{Cr}, \mathrm{Fe}_{3} \mathrm{C}, \mathrm{Fe}_{23} \mathrm{~B}_{6}, \mathrm{Fe}_{23}(\mathrm{C}, \mathrm{B})_{6}, \mathrm{TiC}$ and $\mathrm{Ti}(\mathrm{CN})$, whereas the cladding layers with ex-situ TiC consisted of $\alpha-\mathrm{Fe}, \mathrm{Cr}, \mathrm{Cr}_{23} \mathrm{C}_{6}, \mathrm{TiC}$, and $\mathrm{Ti}(\mathrm{CN})$. $\mathrm{TiC}$ and $\mathrm{Ti}(\mathrm{CN})$ particles were uniformly distributed in the two types of cladding layers. $\mathrm{TiC}, \mathrm{Ti}(\mathrm{CN})$, and other ceramic phases reduced the relative area of $\alpha-\mathrm{Fe}$ in the anode region of the cladding layer; hence, the surface rust layer was not easily peeled off, and the corrosion rate was effectively reduced. The corrosion resistance of the cladding layers significantly increased due to the formation of TiC particles and other compound phases. The Fe-based plasma cladding layer with in-situ TiC particles exhibited the best corrosion resistance.

Keywords: Plasma cladding, Composite layer, Titanium carbide, Corrosion behaviors

\section{FULL TEXT}

(C) 2019 The Authors. Published by ESG (www.electrochemsci.org). This article is an open access article distributed under the terms and conditions of the Creative Commons Attribution license (http://creativecommons.org/licenses/by/4.0/). 